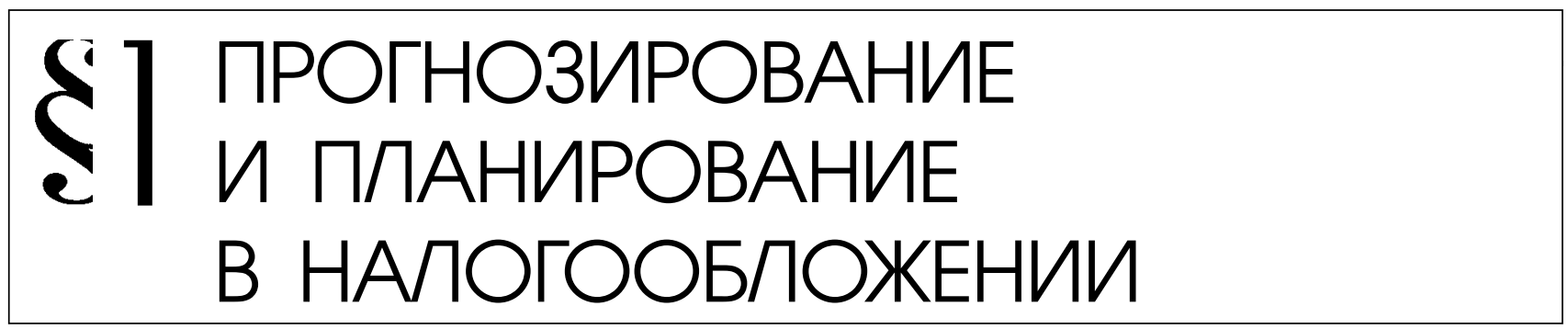

Л.С. Кирина

\title{
ОЦЕНКА НАПРАВЛЕНИЙ СОВЕРШЕНСТВОВАНИЯ НАЛОГОВОЙ ПОЛИТИКИ В РОССИЙСКОЙ ФЕДЕРАЦИИ
}

\begin{abstract}
Аннотация: Налоги, как историческая категория, присущи каждому государству на любом этапе его развития. Более того, налоги являются финансовой основой существования и развития государства. Иные источники государственных финансовых ресурсов не носят такого постоянного характера и не способны долго поддерживать финансовую стабильность. В общем виде, совокупность налогов и сборов, действующих в определённом государстве на конкретном этапе его исторического развития, субъектов налогообложения и налогового законодательства принято называть налоговой системой. Для должного управления налоговой системой в государстве формируется налоговая политика. Характер налоговой политики определяет многие среры развития государства и общества. $B$ ходе подготовки статьи были использованы принципы исторического, экспертного, статистического, логического и сравнительного анализа, а также системный подход и приёмы графической интерпретации. К числу основных научных результатов, определяющих новизну статьи можно отнести: определение специфических особенностей категории "налоговая политика государства»; уточнение и теоретическое обоснование места налоговой политики государства в составе финансовой политики и в формировании налоговой системы государства; раскрытие взаимосвязи процессов налоговой оптимизации и налогового планирования, отражающая отличительные черты понятий налогового прогнозирования, оптимизации и планирования.
\end{abstract}

Ключевые слова: налоговая политика, налоговое бремя, налог на прибыль, НДС, НДФЛ, налог на недвижимость, налоговая ставка, налоговая льгота, налоговые вычеты, социальная напряженность.

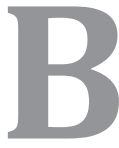

настоящее время и в последующие годы большое значение на российскую экономику по-прежнему будет оказывать конъюнктура мировых цен на энергоносители. Если мировые цены на нефть будут снижаться, то Россия уже не получит таких доходов от экспорта, какие получала ранее. В связи с этим в настоящее время нужно вести поиск новых источников роста доходов консолидированного го- сударственного бюджета, способных влиять на инвестиционный климат в России, состояние производства и его структуру, потребительский спрос. Таким фактором, по нашему мнению, может выступить система налогообложения. Однако существующей налоговой модели необходимо придать более действенную регулирующую и стимулирующую направленность с целью решения задач социально-экономической 
динамики и выхода на инновационную траекторию развития России.

Перейдем к детальному рассмотрению роли системы налогообложения в обеспечении экономического подъема. При этом не следует забывать также о реализации экономических интересов субъектов экономики, в том числе и через налоговую политику.

Общеизвестно, что экономическая политика страны может ориентироваться на конкретные частные интересы (тактическая экономическая политика) или на формальные агрегированные показатели (стратегическая экономическая политика). Современное состояние российской экономики таково, что оно деформирует мотивы и поведение всех экономических агентов - от домохозяйств, тратящих ограниченные накопления на чрезмерное или даже демонстративное потребление, и предприятий, опасающихся выходить за рамки освоенной рыночной ниши, до государства, стремящегося в начале становления налоговой системы к максимальному изъятию доходов с помощью налогообложения у потенциальных налогоплательщиков, а в настоящее время - к не всегда обоснованной, а в отдельных позициях чрезмерной либерализации, не заботясь в должной мере о своем будущем потенциальном доходе. Итоги этой ситуации известны: никто не хочет инвестировать и каждый боится за свою собственность и распоряжается ею с целью получения быстрого эффекта. Эффективно задействовать имеющиеся ресурсы удается лишь при условии реализации государством таких мер, которые позволят существенно изменить мотивацию всех экономических агентов. Это предполагает:

- максимальный учет частных интересов, но не только финансовых олигархов, и устранение препятствий для ро- ста экономической активности фирм и населения;

- снижение тотальной неопределенности и установление предсказуемости политического и экономического курсов правительства для участников экономической деятельности.

Ключевые факторы в экономической сфере сегодня - это налоги и частные инвестиции. Без первых невозможно содержание сильного государства и обеспечение хотя бы минимальных социальных гарантий, без вторых - реструктуризация промышленности и выход на траекторию устойчивого экономического роста на базе инновационной составляющей, с более высокими показателями. Однако и в том, и в другом случае все экономические агенты - фирмы и домохозяйства - должны обладать стимулами и возможностью платить налоги, а также инвестировать и сберегать средства в легальных и цивилизованных формах.

Сущностной характеристикой проводимой в России социально-экономической политики выступает гипертрофированное внимание к финансовому сектору и явно недостаточное внимание к проблемам производственного и научно-технического развития страны. Одна из основных причин этого положения заключается в активно распространяющейся в обществе целевой установки на обогащение. Символом богатства служат деньги. Это обусловило и погоню за ними, и концентрацию внимания властных структур на вопросах денежного обращения и банковского развития.

Не ставя под сомнение огромную роль сырьевого комплекса в экономическом развитии России, согласимся с мнением руководства нашей страны, что путь стратегического развития для России - это переход к экономике инновационного типа. 
Только так можно добиться радикального увеличения объема валового внутреннего продукта - действительно необходимого для повышения уровня жизни населения и сохранения мощи государства.

Практика функционирования и становления налоговой системы России в течение 1992-2013 г.г. убедительно показала, что проблемы налоговой реформы во многом обусловлены финансово-экономическим состоянием предприятий реального сектора экономики - основного базового элемента налогового поля экономики. Некоторое повышение за последние годы уровня рентабельности в отраслях экономики сопровождалось снижением удельного веса убыточных предприятий, однако все равно более 30 \% из них убыточны. В связи с этим вопрос о снижении налогового бремени остается актуальным на протяжении ряда лет, несмотря на опыт ряда развитых стран, где налоговое бремя превышает 50\% (Швеция и др.). В связи с этим самой главной является проблема выбора: за счет какой категории налогоплательщиков осуществить уменьшение налогового бремени, так как это повлечет за собой недополучение денежных средств в бюджет и, как следствие, невыполнение государством своих социальных обязательств в должной мере.

Нет сомнения в том, что активизация государственного вмешательства в экономику должна идти по пути роста налоговой базы и стимулирующего воздействия на нее действующей системы налогообложения, что отражено в принятой Концепции долгосрочного социально-экономического развития Российской Федерации на период до 2020 года, утвержденной распоряжением Правительства РФ от 17 ноября 2008 г. №1662-p. Реализация указанного направления должна производиться путем совер- шенствования налоговой политики, обеспечивающей дополнительные стимулы для:

- создания новых производств, развития бизнеса с высокой добавленной стоимостью, развития малого предпринимательства, прежде всего, в высокотехнологичных секторах экономики;

- обновления и технического перевооружения основных фондов в российской экономике;

- финансирования со стороны работодателей социальных услуг и гарантий своим работникам по получению образования, услуг здравоохранения и пенсионного обеспечения;

- проведения научно-исследовательских и опытно-конструкторских работ, активное содействие внедрения их результатов;

- увеличения глубины переработки природных ресурсов;

- $\quad$ развития российской финансовой инфраструктуры в соответствии с опытом развитых стран;

- повышения экономической активности населения;

- устранения инфраструктурных ограничений экономического роста;

- снижения негативного воздействия производства на окружающую среду и сдерживания выбросов парниковых газов.

Потенциальный уровень доходов бюджетной системы Российской Федерации к 2020 году будет снижаться в первую очередь в результате сокращения доли нефтегазовых доходов в общих доходах бюджетной системы и в валовом внутреннем продукте, а также сокращения доли налогов и сборов для импорта. Повышение собираемости налогов и выход бизнеса из тени должны способствовать поддержанию сбалансированности между расходами и доходами бюджетной системы. 
В результате этих тенденций уровень доходов бюджетной системы Российской Федерации в долгосрочной перспективе при сохранении действующих ставок основных налогов снизится с 39,8 процента валового внутреннего продукта в 2013 году до 34-36 процентов валового внутреннего продукта в 2020 году. Увеличение ставок страховых взносов в государственные внебюджетные фонды будет компенсировано соответствующим снижением ставок налогов, а также другими мерами (субсидии). ${ }^{1}$

Таким образом, на перспективу до 2020 года с учетом выбранной стратегии социально-экономического развития России, ${ }^{2}$ необходимо совершенствовать политику налогообложения по следующим направлениям:

1. Реализация принципов бюджетного федерализма для наделения регионов достаточными собственными ресурсами (при условии самостоятельного развития и наращивания налогового потенциала региона) для достижения субъектами Российской Федерации самостоятельности и автономности в вопросах формирования доходной части бюджетов и выполнения своих расходных обязательств перед гражданами подведомственных территорий.

Для укрепления доходной базы региона необходимо разрешить задачу рационализации и адаптации налоговой политики в регионе к социально-экономическому развитию обслуживаемой территории. Налоги, прежде всего, выполняют распределительную функцию, что позволяет направлять нужные средства для развития наиболее перспективных и базовых отраслей в регионе. Для совершенствования

\footnotetext{
1 Концепция долгосрочного социально-экономического развития Российской Федерации на период до 2020 года. Утверждена распоряжением Правительства РФ от 17 ноября 2008 г. №1662-р.

2 Тот же.
}

региональной налоговой политики, укрепления доходной базы регионов и одновременного устойчивого социально-экономического развития территорий можно предложить следующее:

- последовательное снижение налогового бремени для хозяйствующих субъектов, имеющих особую значимость для региона. (Так, например, в Орловской области в Новодеревеньковском районе Санкт-Петербургская компания «Евросервис-Агро» планирует построить сахарный завод, комбикормовый цех и животноводческий комплекс, которые принесут немалую пользу региону и его жителям. Поэтому имеет смысл при размещении подобных производств предусмотреть налоговые льготы в части региональных и местных налогов );

- поддержка отечественных производителей путем предоставления налоговых льгот, отсрочек налоговых выплат, инвестиционных налоговых кредитов, снижения ставок налогов в рамках имеющейся юрисдикции;

- создание различных форм «налоговых оазисов» в определенных секторах региональной экономики или на отдельных территориях (для регионов Центрального федерального округа - это актуально, так как большинство регионов данного округа имеют специализацию на развитие сельского хозяйства и перерабатывающей промышленности. В связи с этим в регионах необходимо разработать целевую программу по определению стимулирующей региональной налоговой политики, направленной на развитие базовых отраслей экономики);

- $\quad$ развивать законодательное и правовое поле предпринимательской деятельности; 
- $\quad$ осуществить переход от политики подавления доходов к политике их взращивания;

- ввести налоговый механизм стимулирования научно - исследовательских и опытно - конструкторских разработок (НИОКР) на предприятиях региона, позволяющий относить расходы на НИОКР к текущим затратам и в течение года осуществлять их амортизацию;

- создание единого кадастра недвижимости и земель, принадлежащих собственникам.

Таким образом, необходимо дать возможность регионам на основе общих принципов и единого экономического пространства «заработать» на региональных и местных налогах, а также на региональных местных неналоговых доходах. Региональные (местные) налоговые системы для эффективного своего воздействия должны охватывать всю совокупность производственных отношений в регионе и в равной мере обслуживать хозяйствующих субъектов всех форм собственности, исключая малейшую возможность дискриминации налогоплательщиков в зависимости от организационно - правовой формы предприятия, способствуя при этом формированию и усилению стимулов экономической деятельности в регионе. Сформировавшаяся в настоящее время в России система налогообложения, в том числе и в регионах, в отличие от стран с развитой рыночной экономикой по сути блокирует важнейший источник внутренних инвестиций - доход, капитализируемый хозяйствующими субъектами. Отсутствуют стимулы для активизации предпринимательских усилий в сфере материального производства и в сфере производства инновационной продукции.

2. Ослабление налоговой нагрузки на предприятия производственной сферы за счет использования специальных инвестиционных льгот и одновременное усиление налогового контроля за предприятиями, занятыми в отраслях со значительным теневым оборотом (в т.ч. установление особого контроля за предприятиями, осуществляющими операции в офшорных зонах, принятие законов, ограничивающих возможность ухода от налогообложения посредством применения трансфертных цен при операциях между зависимыми организациями - вот основные пути стабилизации налоговых доходов).

3. Имущественные налоги. Усиление налогового бремени по имущественным налогам, осуществив переход к налогу недвижимость путем привлечения к налогообложению владельцев элитной недвижимости и транспортных средств.

4. Налог на доходы физических лиц. Постепенный переход к прогрессивному налогообложению индивидуальных доходов физических лиц, что позволит повысить уровень личных доходов низкодоходных слоев населения, добиться более справедливого подхода в установлении налога на доходы физических лиц и снижение бедности до уровня, характерного для развитых стран, а также снижения социального неравенства. Нельзя не признать, что введение плоской шкалы налога на доходы физических лиц позволило добиться в существенной мере вывода заработной платы из тени и увеличения его собираемости. Примечателен в рассматриваемом контексте тот факт, что в период с 2000 г. по 2013 г. ежемесячный денежный доход на душу населения за счет легитимной оплаты труда возрос с 2 501,9 руб. до 16 940,0 руб., то есть почти в 7 раз.

В то же время следует отметить, что пример российской практики по НДФЛ не отвечает зарубежному опыту по величи- 
не налоговой ставки (США - от 15\% до $39,6 \%$; Франция от 0 до 56,8\%; Германия от $19 \%$ до 53\%); отсутствию прогрессии и реализации принципов справедливости. $\mathrm{C}$ учетом реальных доходов россиян и дифференциации доходов у различных групп населения (более 15 раз) складывается впечатление, что послабление подоходного налога с 2001 года направлено в пользу людей с высокими доходами и олигархической верхушки.

Целесообразно также последовательно сокращать налоговую нагрузку на малообеспеченные слои населения за счет увеличения социальных налоговых вычетов, совершенствовать в стимулирующих целях механизмы налогообложения доходов населения (введение налога на недвижимость, зависящего от рыночной стоимости объектов недвижимости). Реформирование налогов и взносов на социальные нужды должно проводиться в увязке с реформой систем пенсионного, медицинского и социального страхования.

\section{5. Налог на прибыль организаций.} Для обеспечения прироста чистой прибыли хозяйствующим субъектам в определенных отраслях экономики можно предложить оптимальную дифференциацию ставок налога на прибыль организаций в зависимости от уровня затрат, которую можно реализовать региональным властям в части принадлежащей территориям суммы этого налога.

Кроме того, в отдельных отраслях экономики затраты на производство весьма высоки и имеют тенденцию к увеличению: транспорт-83,2-85,8\%,промышленность$74,9-78,6 \%$. В жилищно-коммунальной сфере систематически наблюдается превышение затрат над выручкой, что не без основания вызывает особую обеспокоенность у первых лиц нашего государства.
Несомненно, такой фактор как затраты при дифференцированном подходе к установлению ставки налога на прибыль организаций имеет большое значение, так как позволит учитывать энерго- и материалоемкость продукции, природные, рентные и другие факторы, определяющие себестоимость продукции в различных отраслях экономики страны.

Амортизационные отчисления. Рассматривая существующие механизмы взаимодействия государства и хозяйствующих субъектов в области налогообложения прибыли (дохода) нельзя не отметить наличие своего рода неотъемлемых элементов регулирующего характера, свойственных налоговым системам подавляющего большинства экономически развитых стран. С точки зрения инвестиционной направленности одним из важнейших является амортизационная политика. В отношении основных фондов стремление государства стимулировать производственную деятельность проявляется в виде разрешения ускоренного списания стоимости таких фондов. При этом режим ускоренной амортизации является разрешенным лишь для предприятий тех отраслей (или сфер экономики), которые в рамках данной государственной политики рассматриваются в качестве приоритетных. Так, например, во Франции нелинейная амортизация применяется исключительно в промышленности на промышленном оборудовании, в США в обрабатывающей промышленности.

Ускоренная амортизация уменьшает прибыль на гораздо большую величину, чем сумма действительного износа основных фондов, а это дает предприятию возможность быстрее возместить стоимость основных средств и, следовательно, обновить их. Применение ускоренной амортизации целесообразно для активной части 
основных средств, таких, как машины и оборудование.

В российском законодательстве применение ускоренной амортизации активной части основных производственных фондов предусмотрено для высокотехнологичных отраслей и эффективных видов машин и оборудования. Действующая амортизационная система по-прежнему требует совершенствования, так как новая амортизационная система пока еще не стала эффективным инструментом стимулирования инвестиционной активности в национальной экономике. Кроме того, по данным Росстата, хозяйствующие субъекты практически не применяют ускоренные методы расчета амортизации.

Ослаблен контроль за использованием амортизационных отчислений на цели воспроизводства основных фондов (т.е. инвестиции). Хозяйствующие субъекты различных форм собственности распыляют амортизационные отчисления, используют их в составе оборотных средств, на выплату заработной платы, резервируют на банковских депозитах с целью получения высокого дохода в виде депозитного банковского процента и т.д.

Для того чтобы усилить целевое использование амортизационных отчислений на инвестиции в основной капитал, целесообразно:

- ввести систему административной, дисциплинарной и экономической ответственности руководителей предприятий и организаций за целевое использование амортизационных отчислений;

- создать особые счета для учета начисления и движения амортизационного фонда, позволяющие отделить амортизационные отчисления от оборотных средств предприятий и предотвратить практику их отвлечения на цели, не связанные с воспроизводством основных фондов;

- приведение балансовой стоимости основных средств в соответствие с их текущей рыночной стоимостью посредством переоценки (в этом случае переоценку необходимо производить добровольно и с использованием исключительно рыночных методов оценки);

- предусмотреть систему налоговых вычетов по налогу на прибыль организаций в случае целевого использования хозяйствующим субъектом сумм амортизации, начисленной с учетом переоценки;

- установить штрафы за нецелевое использование амортизационных отчислений.

Наряду с этим необходимо совершенствовать амортизационную политику для целей налогообложения в части сокращения сроков полезного использования машин и оборудования, а также повышения размера амортизационной премии до 30 процентов по активной части основных фондов. Усиление регулирующей функции амортизации ускорит внедрение инновационных и технологических новшеств.

\section{6. Применение форм налогового сти-} мулирования. При наличии перечисленных выше макроэкономических условий становится возможным стимулирование, в т.ч. посредством применяемой системы налогообложения, конечного спроса на отечественные товары для формирования инициирующего импульса роста производства. Конкретные же направления и меры этого стимулирования таковы:

а) проведение при наличии свободных производственных мощностей политики импортозамещения посредством протекционистских мер внешнетор- 
говой политики, государственных закупок и инвестиций на модернизацию и повышение конкурентоспособности отечественного производства, ориентируясь, прежде всего, на стратегические отрасли экономики (машино- и авиастроение, космические исследования, биотехнология и другие);

б) увеличение государственных закупок отечественных товаров в России в целях удовлетворения общественных нужд нации, модернизации жилищнокоммунального сектора, учреждений здравоохранения, образования, культуры и других сфер;

в) установление правительственного контроля за закупками промышленного оборудования для государственных нужд, проводимых на конкурсной основе, а также для контролируемых государством предприятий (прежде всего - естественных монополий) с целью их ориентации на закупки конкурентоспособного отечественного оборудования и прекращение использования бюджетных средств на импорт товаров и услуг, аналоги которых производятся в России;

г) реализация законодательно предусмотренных требований по закупке отечественного оборудования инвесторами, осваивающими месторождения природных ресурсов на условиях соглашений о разделе продукции или концессий;

д) увеличение доходов граждан, занятых в бюджетной сфере посредством индексации заработной платы и выведение из-под обложения величины прожиточного минимума;

е) установление ограничений опережающего роста заработной платы на предприятиях у руководящего состава по сравнению с наемными работниками (например, 5: 1).
Конкретно в области налоговой политики можно рекомендовать следующие меры:

\section{7. Унификация российского налого-} вого законодательства в соответствии с нормами международного налогового законодательства. Механизмы налоговой политики, в том числе администрирования налогов и сборов, должны предусматривать упрощение налоговой системы, снижение издержек налогоплательщиков, связанных с исполнением налогового законодательства, стимулировать перемещение финансовых центров и центров прибыли корпораций из стран с пониженным налогообложением в Россию. Весьма важной процедурой для российских налогоплательщиков, позволяющей им оставаться в статусе «законопослушного» налогоплательщика, является упрощение процедуры рассрочки (отсрочки) задолженности юридических лиц по налогам и сборам, а также по пеням и штрафам в части увеличения сроков и упрощения процедуры.

Придание импульса российской экономике за счет налоговых факторов невозможно без серьезной трансформации структурообразующих элементов системы, включая создание регулирующего налогового механизма, поэтому данные меры экономической политики рассматриваются в единстве с необходимыми изменениями в структуре и характере институтов регулирования экономики.

Для создания регулирующего налогового механизма недостаточно рассмотрения общих перспектив реформирования системы налогообложения в России, следует уделить внимание отдельным основным налогам, или их группам, имеющим значение для российской действительности. Необходимые изменения, которые обобщены и представлены ниже. 
DOI: $10.7256 / 1812-8688.2014 .2 .11098$

При цитировании этой статьи сноска на doi обязательна

Прогнозирование и планирование в налогообложении

Рекомендуемые изменения в российском законодательстве по отдельным видам налогов

\begin{tabular}{|c|c|}
\hline Вид налога & Характер предлагаемых изменений \\
\hline 1 & 2 \\
\hline $\begin{array}{l}\text { 1. Налог на } \\
\text { добавленную } \\
\text { стоимость }\end{array}$ & $\begin{array}{l}\text { 1. Уточнение налоговой базы по налогу за счет выведения из-под } \\
\text { налогообложения элементов, не имеющих отношения к «добавлен- } \\
\text { ной стоимости»- амортизационных отчислений; авансовых плате- } \\
\text { жей в счет предстоящих поставок и других, искажающих назначе- } \\
\text { ние налога; } \\
\text { 2. Совершенствование процедуры исчисления и возмещения налога } \\
\text { на добавленную стоимость; } \\
\text { 3. Полное освобождение от налога операций, направленных на сти- } \\
\text { мулирование экономического подъема промышленного и сельско- } \\
\text { хозяйственного производства; } \\
\text { 4. Упрощение вычета по налогу на добавленную стоимость по вы- } \\
\text { данным и полученным авансам; } \\
\text { 5. Строгая регламентация доли налога, остающейся субъектам РФ; } \\
\text { 6. Поэтапное снижение НдС до уровня ставок налога в странах с раз- } \\
\text { витой рыночной экономикой (12-14\%) и смещение его в сферу об- } \\
\text { ращения, т.е. переход к налогу с продаж. }\end{array}$ \\
\hline $\begin{array}{l}\text { 2. Налог на прибыль } \\
\text { организаций }\end{array}$ & $\begin{array}{l}\text { 1. При фиксированном пределе рентабельности на продукцию } \\
\text { предприятий - монополистов, его превышение облагать прогрес- } \\
\text { сивным налогом, носящим конфискационный характер - налогом } \\
\text { на сверхприбыль; } \\
\text { 2. Создание общего инвестиционного фонда (по опыту Швеции), за } \\
\text { счет постепенного накопления части прибыли предприятиями на } \\
\text { специальных счетах для закупки нового оборудования, финансиро- } \\
\text { вания расходов по НИОКР. В случае изъятия средств фонда и направ- } \\
\text { ления их на другие цели целесообразно применять систему штра- } \\
\text { фов и подвергать обложению расходуемые суммы; } \\
\text { 3. Расширение прав предприятий в применении амортизации (обыч- } \\
\text { ной и ускоренной) с одновременным контролем за использованием } \\
\text { амортизационных отчислений; } \\
\text { 4. Введение консолидированной отчетности по налогу на прибыль } \\
\text { для холдингов; } \\
\text { 5. Переоценка балансовой стоимости основных средств с целью со- } \\
\text { ответствия их рыночной стоимости. }\end{array}$ \\
\hline $\begin{array}{l}\text { 3.Налог на доходы } \\
\text { физических лиц }\end{array}$ & $\begin{array}{l}\text { 1. Переход к прогрессивному налогообложению. } \\
\text { 2. Требует пересмотра система льгот по НДФЛ: } \\
\text { - для соблюдения принципа равенства и социальной справедли- } \\
\text { вости необходимо ввести необлагаемый минимум, соответству- } \\
\text { ющий прожиточному минимуму, а не минимальной заработной }\end{array}$ \\
\hline
\end{tabular}


DOI: 10.7256/1812-8688.2014.2.11098

При цитировании этой статьи сноска на doi обязательна

Налоги и налогообложение - №2(103)• 2014

\begin{tabular}{|c|c|}
\hline 1 & 2 \\
\hline & $\begin{array}{l}\text { плате (или твердой сумме), установленной в соответствии с Зако- } \\
\text { ном. Причем необходимо использование дифференцированной ве- } \\
\text { личины прожиточного минимума в зависимости от региона прожи- } \\
\text { вания плательщика. } \\
\text { • сокращение различного рода льгот, связанных с выведением опре- } \\
\text { деленной суммы зарплаты, необоснованно установленных разме- } \\
\text { ров (так, например, у «чернобыльцев» ежемесячно вычитается из } \\
\text { дохода } 3000 \text { рублей», а «афганцев» - } 500 \text { рублей); } \\
\text { • введение льгот, стимулирующих отчисления средств на социаль- } \\
\text { ные цели, а также поощрение капиталовложений в производство; } \\
\text { • кроме вышеперечисленных льгот следует вычитать из облагаемо- } \\
\text { го совокупного дохода непредвиденные расходы: затраты на про- } \\
\text { фессиональное обучение как самого физического лица, так и его } \\
\text { детей (подобный порядок установлен в Германии, где принимается } \\
\text { во внимание проживание обучающегося лица, т.е. или в домашних } \\
\text { условиях или в другом городе); затраты на пребывание в интернате } \\
\text { и паушальные (твердые) суммы на содержание инвалидов в зави- } \\
\text { симости от степени и вида инвалидности; затраты в случае потери } \\
\text { кормильца. С введением подобной системы обложения возможно } \\
\text { составление деклараций в раздельном или семейном начислении (с } \\
\text { учетом корректировки необлагаемого минимума, сумм непредви- } \\
\text { денных расходов и т. д.) } \\
\text { 3.Отмена налога на доходы физических лиц по операциям по вкла- } \\
\text { дам в банках, что снижает инвестиционную активность населения. } \\
\text { 4. Отказ от НдФЛ с суммы заработной платы, выплачиваемой работ- } \\
\text { никам бюджетной сферы. } \\
\text { 5.Организация должного учета налогоплательщиков, получающих } \\
\text { доходы от сдачи внаем квартир и других жилых и нежилых поме- } \\
\text { щений. } \\
\text { 6.Установление повышенной ставки НдФл на доходы руководите- } \\
\text { лей предприятий, превышающих паритет в заработной плате с на- } \\
\text { емными работниками (5:1). } \\
\text { 7.Переход к семейному декларированию налога на доходы физиче- } \\
\text { ских лиц; } \\
\text { 8.Переход на уплату налога по месту жительства граждан, т.е. по ме- } \\
\text { сту получения бюджетных услуг. }\end{array}$ \\
\hline $\begin{array}{l}\text { 4. Страховые плате- } \\
\text { жи во внебюджет- } \\
\text { ные фонды }\end{array}$ & $\begin{array}{l}\text { 1.Осуществление страхового взноса на обязательное социальное } \\
\text { страхование, устанавливаемого в размере, обеспечивающем ста- } \\
\text { бильность и устойчивость функционирования пенсионной систе- } \\
\text { мы, а также систем обязательного медицинского и социального } \\
\text { страхования; }\end{array}$ \\
\hline
\end{tabular}




\begin{tabular}{|c|c|}
\hline & $\begin{array}{l}\text { 2. Снижение основной ставки до } 20 \% \text { в соответствии с мировой тен- } \\
\text { денцией и применение пониженной ставки для субъектов малого } \\
\text { бизнеса; } \\
\text { 3. Расширение круга налогоплательщиков, имеющих право приме- } \\
\text { нять регрессивную шкалу налогообложения ( повышение налого- } \\
\text { вой база за счет повышения заработной платы основной категории } \\
\text { налогоплательщиков); } \\
\text { 4. Перенос части нагрузки по уплате страховых взносов с работода- } \\
\text { телей на работников. }\end{array}$ \\
\hline $\begin{array}{l}\text { 5. Акцизы отдель- } \\
\text { ные группы } \\
\text { и виды товаров }\end{array}$ & $\begin{array}{l}\text { 1.Упорядочение повышения ставок акцизов в пределах инфляцион- } \\
\text { ного ожидания на предстоящий бюджетный год; } \\
\text { 2. Совершенствование системы взимания акцизов и унификацию } \\
\text { ставок вывозных пошлин на нефтепродукты в целях стимулирова- } \\
\text { ния производства продуктов высокого передела; } \\
\text { 3.Постепенное восстановление монополии государства на продажу } \\
\text { топливно-энергетических и сырьевых ресурсов, ликероводочных и } \\
\text { табачных изделий с допуском коммерческих структур к продвиже- } \\
\text { нию подобной продукции на рынок и выплатой комиссионного воз- } \\
\text { награждения до 1-2\%; } \\
\text { 4.Более четкое разграничение полномочий по взиманию акцизов } \\
\text { между звеньями бюджетной системы, закрепление твердых обяза- } \\
\text { тельств за регионами. }\end{array}$ \\
\hline $\begin{array}{l}\text { 6. Налог на добычу } \\
\text { полезных } \\
\text { ископаемых }\end{array}$ & $\begin{array}{l}\text { 1. Повышение роли ресурсных платежей и увеличение налоговых } \\
\text { платежей за добычу и реализацию на экспорт природных ресурсов } \\
\text { при установлении лимитов на экспорт природных ресурсов. } \\
\text { 2. Применение льготного налогообложения при ведении поиска но- } \\
\text { вых месторождений природных ресурсов и их разработку. } \\
\text { 3. Ссовершенствование системы налогообложения добычи нефти } \\
\text { для стимулирования разработки новых месторождений и полно- } \\
\text { го использования потенциала уже разрабатываемых месторожде- } \\
\text { ний; } \\
\text { 4. Предоставление права субъектам РФ принимать участие в опре- } \\
\text { делении норм и ставок подобных отчислений. }\end{array}$ \\
\hline $\begin{array}{l}\text { 7.Специальные } \\
\text { налоговые режимы } \\
\text { 7.1. Единый налог } \\
\text { на вмененный } \\
\text { доход }\end{array}$ & $\begin{array}{l}\text { 1. Более обоснованное установление базовой доходности с предо- } \\
\text { ставлением ее корректировки региональным властям с учетом } \\
\text { уровня социально-экономического развития региона; } \\
\text { 2. Перевод на уплату данного налога такого вида деятельности, как } \\
\text { передача во временное владение или пользование другим хозяй- } \\
\text { ствующим субъектам нежилых помещений общей площадью не бо- } \\
\text { лее } 150 \text { кв.м.; }\end{array}$ \\
\hline
\end{tabular}




\begin{tabular}{|c|c|}
\hline & $\begin{array}{l}\text { 3. Оспариваемая возможность для налогоплательщиков перерас- } \\
\text { чета налоговых обязательств, если доход, рассчитанный по ЕНВД, } \\
\text { окажется больше, нежели при традиционной системе налогообло- } \\
\text { жения; } \\
\text { 4. Разработка на федеральном уровне единой методики, по- } \\
\text { зволяющей муниципальным образованиям при расчете коэф- } \\
\text { фициента К2 учесть такие особенности ведения предпринима- } \\
\text { тельской деятельности, как: территориальное расположение } \\
\text { объекта хозяйствования, его доходность с учетом сезонного } \\
\text { фактора (если это имеет место), времени работы, вида реализу- } \\
\text { емой продукции. }\end{array}$ \\
\hline $\begin{array}{l}\text { 7.2. Единый сель- } \\
\text { скохозяйственный } \\
\text { налог }\end{array}$ & $\begin{array}{l}\text { 1. Обоснование дополнительного перечня расходов при формирова- } \\
\text { нии налоговой базы, учитывая специфику сельскохозяйственного } \\
\text { производства. }\end{array}$ \\
\hline $\begin{array}{l}\text { 7.3. Упрощенная } \\
\text { система налогообло- } \\
\text { жения }\end{array}$ & $\begin{array}{l}\text { 1. Ежегодная индексация суммы годового оборота, позволяющего } \\
\text { перейти на упрощенную систему налогообложения; } \\
\text { 2. Ввести для налогоплательщиков, использующих упрощенную си- } \\
\text { стему налогообложения, начисление и уплату НДС; } \\
\text { 3. Перевод субъектов, применяющих упрощенную систему налого- } \\
\text { обложения, с поквартального представления налоговых деклара- } \\
\text { ций на годовую налоговую декларацию с уплатой ежеквартальных } \\
\text { авансовых взносов налога исходя из объекта налогообложения. }\end{array}$ \\
\hline спортный & $\begin{array}{l}\text { 1. Дифференциация ставок транспортного налога для физических и } \\
\text { юридических лиц, а также в зависимости от страны происхождения } \\
\text { автомобиля (те. увеличение должно коснуться иностранных авто- } \\
\text { мобилей); } \\
\text { 2. Предусмотреть возможность применения повышающего коэффи- } \\
\text { циента к ставке данного налога при предельном сроке эксплуата- } \\
\text { ции автомобиля (более } 10 \text { лет). }\end{array}$ \\
\hline $\begin{array}{l}\text { 9. Поимуществен- } \\
\text { ные налоги } \\
\text { (с юридических } \\
\text { и физических лиц) } \\
\text { на недвижимость }\end{array}$ & $\begin{array}{l}\text { 1. Формирование интегрального кадастра объектов недвижимости } \\
\text { по различным категориям (государственная недвижимость; личная } \\
\text { недвижимость; недвижимость организаций; объекты незавершен- } \\
\text { ного строительства); } \\
\text { 2. Установление дифференцированных ставок налога на недвижи- } \\
\text { мость для юридических и физических лиц; } \\
\text { 3. Введение «налоговых каникул» для вновь создаваемых произ- } \\
\text { водств; } \\
\text { 4. Установление базовой ставки налога для физических лиц на уров- } \\
\text { не 0,36-0,47 \% от рыночной стоимости; } \\
\text { 5. Использование повышающих коэффициентов по недвижимости, } \\
\text { расположенной в пределах городской черты или вблизи ее (в преде- } \\
\text { лах } 15 \text { км); }\end{array}$ \\
\hline
\end{tabular}




\begin{tabular}{|c|c|}
\hline & $\begin{array}{l}\text { 6. Использование повышающих коэффициентов при строительстве } \\
\text { жилых домов повышенной этажности (выше 2-го этажа); } \\
\text { 7. Введение необлагаемого минимума в } 500 \text { тыс. рублей для героев } \\
\text { Советского Союза, Российской Федерации, инвалидов детства, инва- } \\
\text { лидов } 1,2 \text { групп и др. категорий; } \\
\text { 8. Использование повышающих коэффициентов при превышении } \\
\text { норм жилой площади на семью (на семью из трех человек 50-60 кв.м). }\end{array}$ \\
\hline $\begin{array}{l}\text { 10. Земельный } \\
\text { алог }\end{array}$ & $\begin{array}{l}\text { 1. Организовать учет налогоплательщиков земельного налога; } \\
\text { 2. Наладить тесную взаимосвязь с регистрирующими органами, ве- } \\
\text { дущими учет собственников жилья и недвижимости; } \\
\text { 3. Ревизия подведомственных земель местными органами власти и } \\
\text { выявление невостребованных земель; } \\
\text { 4. Применение местными органами власти экономически обосно- } \\
\text { ванных ставок и льгот по налогу; } \\
\text { 5. Для местных органов власти закрепить периодичность пересмо- } \\
\text { тра кадастровой стоимости земли и порядок разрешения споров, } \\
\text { связанных с оценкой земель; } \\
\text { 6. Закрепить методологический подход по установлению арендной } \\
\text { платы за землю в процентах от кадастровой стоимости земельных } \\
\text { участков ; } \\
\text { 7. Внести поправки в Жилищный кодекс РФ в части возникновения } \\
\text { права общей долевой собственности на земельный участок с соот- } \\
\text { ветствующей регистрацией этого права; } \\
\text { 8. Уточнить порядок уплаты земельного налога в случае пользова- } \\
\text { ния земельным участком, но при отсутствии зарегистрированного } \\
\text { права на него. }\end{array}$ \\
\hline
\end{tabular}

Для мобилизации налоговых поступлений в бюджетную систему России необходимо, прежде всего, повышение заинтересованности граждан России и юридических лиц в полной и своевременной уплате налогов. Одно из направлений обеспечение «прозрачности» расходования бюджетных средств путем доведения налоговыми и финансовыми органами в доступной форме до налогоплательщиков информации о суммах поступивших и израсходованных налогов и направлениях их использования, анализ проблем, возникающих при финансировании социальной и иных бюджетных сфер, имеющихся резер- вов увеличения поступлений и подготовка конкретных предложений по исправлению ситуации. Весьма важным представляется также введение в образовательные программы не только высших, но и средних учебных заведениях предметов, раскрывающих вопросы формирования и расходования средств бюджетной системы и разъясняющих обязанности каждого члена общества по уплате налогов. 


\section{Библиография:}

1. Концепция долгосрочного социально-экономического развития Российской Федерации на период до 2020года. Утверждена распоряжением Правительства РФ от 17 ноября 2008г. №1662-p.

2. Абрамов М.Д. Вопросы совершенствования налоговой системы России // Налоговые споры: Теория и практика.-2012. - № 9.

3. Ильин А.Ю. Основные направления и формы реализации государственной налоговой политики налоговыми органами // Налоги. 2013. N 2.

4. Налоги и налогообложение. Учебник / Под ред. профессора Г.Б. Поляка - М.: ЮрайтИздат - М., 2012.

5. Савина О.Н. Налоговые риски государства в условиях реализации налоговой политики по стимулированию инновационной деятельности в России // Международный бухгалтерский учет. 2013. N 45.

6. Соловьев И. Эффективность налоговых льгот как элемента корректировки налоговой политики государства // Налоговый вестник. 2013. N 11.

7. www.minfin.ru

8. Агузарова Ф.С. Некоторые вопросы модернизации налоговой системы Российской Федерации // NB: Финансовое право и управление. - 2013. - 2. - C. 24-44. URL: http://www.e-notabene.ru/flc/article_629.html.

9. Цалиев А.М. Расширение роли субъектов Российской Федерации в государственной политике // NB: Вопросы права и политики. - 2013. - 3. - C. 21-94. DOI: 10.7256/2305-9699.2013.3.554. URL: http://www.e-notabene.ru/lr/article_554.html

10. Оробинская И.В.. Основы оптимизации налогообложения сельскохозяйственных товаропроизводителей в России . // Налоги и налогообложение. - 2013. № 11 . C. 807-817. DOI: .10.7256/1812-8688.2013.11.9584.

11. Л.Л. Арзуманова. Финансовая политика государства: понятие и ее составные элементы. //Финансовоеправо иуправление. - 2013. - № 1.—C.72-78. DOI:.10.7256/.2013.1.9525.

12. Баженов А.А.. Проблема обеспечения тождественности расчетов между организацией и налоговым органом. // Налоги и налогообложение. - 2013. - № 7. - С. 504-511. DOI: .10.7256/1812-8688.2013.7.913

\section{References:}

1. Kontseptsiya dolgosrochnogo sotsial'no-ekonomicheskogo razvitiya Rossiiskoi Federatsii na period do 2020goda. Utverzhdena rasporyazheniem Pravitel'stva RF ot 17 noyabrya 2008g. №1662-r.

2. Abramov M.D. Voprosy sovershenstvovaniya nalogovoi sistemy Rossii // Nalogovye spory: Teoriya i praktika. - 2012. — № 9.

3. Il'in A.Yu. Osnovnye napravleniya i formy realizatsii gosudarstvennoi nalogovoi politiki nalogovymi organami // Nalogi. 2013. N 2.

4. Nalogi i nalogooblozhenie. Uchebnik / Pod red. professora G.B. Polyaka - M.: Yurait-Izdat M., 2012. 
5. Savina O.N. Nalogovye riski gosudarstva v usloviyakh realizatsii nalogovoi politiki po stimulirovaniyu innovatsionnoi deyatel'nosti v Rossii // Mezhdunarodnyi bukhgalterskii uchet. 2013. N 45.

6. Solov'ev I. Effektivnost' nalogovykh l'got kak elementa korrektirovki nalogovoi politiki gosudarstva // Nalogovyi vestnik. 2013. N 11.

7. www.minfin.ru

8. Aguzarova F.S. Nekotorye voprosy modernizatsii nalogovoi sistemy Rossiiskoi Federatsii // NB: Finansovoe pravo i upravlenie. - 2013. - 2. - C. 24-44. URL: http://www.e-notabene. $\mathrm{ru} / \mathrm{flc} /$ article_629.html.

9. Tsaliev A.M. Rasshirenie roli sub"ektov Rossiiskoi Federatsii v gosudarstvennoi politike // NB: Voprosy prava i politiki. - 2013. - 3. - C. 21-94. DOI: 10.7256/2305-9699.2013.3.554. URL: http://www.e-notabene.ru/lr/article_554.html

10. Orobinskaya I.V.. Osnovy optimizatsii nalogooblozheniya sel'skokhozyaistvennykh tovaroproizvoditelei v Rossii . // Nalogi i nalogooblozhenie. — 2013. — № 11. - C. 807-817. DOI: .10.7256/1812-8688.2013.11.9584.

11. L.L. Arzumanova. Finansovaya politika gosudarstva: ponyatie i ee sostavnye elementy. // Finansovoe pravo i upravlenie. — 2013. — № 1. — C. 72-78. DOI: .10.7256/.2013.1.9525.

12. Bazhenov A.A.. Problema obespecheniya tozhdestvennosti raschetov mezhdu organizatsiei i nalogovym organom. // Nalogi i nalogooblozhenie. — 2013. - № 7. - C. 504-511. DOI: .10.7256/1812-8688.2013.7.913 